\title{
Cancer Antigen 125 Serum Level in Head and Neck Diffuse Large B-Cell Lymphoma
}

\author{
Igor Hutabarat, Agung Dinasti Permana, Yussy Afriani Dewi \\ Department of Otorhinolaryngology Head and Neck Surgery Faculty of Medicine \\ Universitas Padjadjaran/Dr. Hasan Sadikin General Hospital Bandung, Indonesia
}

\begin{abstract}
Background: Diffuse Large B-Cell Lymphoma (DLBCL) is the most common subtype of the NonHodgkin Lymphoma (LNH). Until now, lactate dehydrogenase (LDH) is the only tumor marker to assess DLBCL progression; however, increased LDH is a relatively non-specific biomarker. Cancer antigen 125 (CA-125) serum level have been used as a tumor marker in ovarian cancer. The aim of this study was to explore the possible role of CA-125 serum level as a tumor marker in head and neck DLBCL.

Methods: This was an observational descriptive study among consecutively sampled DLBCL patients. CA-125 serum level examination was carried out (ADVIA Centaur CA-125II) and described along with the clinical characteristics of DLBCL patients.

Results: DLBCL was mostly observed in males (54.05\%), most often in the 55-65 year age group $(51.3 \%)$, with stage 1 DLBCL was the most prevalent (71.9\%). The mean CA-125 serum level was 22.9 $\mathrm{U} / \mathrm{ml}$ and increased in patients with advanced DLBCL.

Conclusions: Increased CA-125 serum level in DLBCL, especially at advanced stages, suggests that CA125 serum level may be of benefit as a tumor marker in the head and neck DLBCL. Further study is in need to explore the role of CA-125.
\end{abstract}

Keywords: Cancer antigen 125, diffuse Large B-cell Lymphoma, lactate dehydrogenase, non-hodgkin

\section{Introduction}

Diffuse Large B-Cell Lymphoma (DLBCL) is the most often found lymphoma subtype (31\%) of all Non-Hodgkin Lymphoma (LNH). This lymphoma is a unique lymphoid malignant disease because it has different characteristics ranging from clinical symptoms, morphology, immunology, and molecular phenotypes that can affect the treatment and prognosis of the disease. ${ }^{1}$ The LNH is predominantly occurred at a productive age around 45-64 years old and histologically, DLBCL is the most prevalent. Interestingly, there is a correlation between gender, age and clinical diagnosis with histological type lymphoma. ${ }^{2}$

The national basic health research (Riset Kesehatan Dasar, RISKESDAS) conducted by the Ministry of Health Republic of Indonesia in 2013 has shown that the Yogyakarta Province has the highest prevalence of lymphoma, and the West Java Province has the highest estimated number of lymphoma patients with almost 3,000 patients. ${ }^{3}$ The diagnosis of DLBCL is obtained from history, physical examination, routine blood tests, plain chest X-ray, and Computed Tomography (CT) of the head and neck. Establishing a definite diagnosis of DLBCL is obtained from histopathological examination of biopsy tissue in nodules or tumors in the head region of the neck, and the prognosis of DLBCL can be observed with the International Prognostic Index Score (IPI Score). ${ }^{4}$

Nearly two decades ago, LDH is the only biological parameter included in the IPI score for DLBCL. Some studies report the percentage of DLBCL patients with an increase in serum lactate dehydrogenase (LDH) levels which is relatively low, ranging from $10.2 \%$ to $37 \%$. Therefore, new tumor markers are needed as an indicator of disease activity in evaluating treatment success. $^{5}$ Interestingly, high expression of cancer antigen 125 (CA-125) serum levels has been found in LNH patients. DLBCL patients with high CA-125 serum levels

Correspondence: Igor Hutabarat, Department of Otorhinolaryngology Head and Neck Surgery Faculty of Medicine Universitas Padjadjaran/Dr. Hasan Sadikin General Hospital, Jalan Pasteur 38, Bandung, West Java- Indonesia, E-mail: igorhutabarat@gmail.com 
Table 1 Characteristics of Diffuse Large B-Cell Lymphoma Patients at Dr. Hasan Sadikin General Hospital, Bandung

\begin{tabular}{|c|c|c|}
\hline Parameters & $\mathbf{n}$ & $\%$ \\
\hline \multicolumn{3}{|l|}{ Sex } \\
\hline Male & 20 & 54.05 \\
\hline Female & 17 & 45.95 \\
\hline \multicolumn{3}{|l|}{ Age (years) } \\
\hline $17-25$ & 1 & 2.7 \\
\hline $26-35$ & - & - \\
\hline $36-45$ & 1 & 2.7 \\
\hline $46-55$ & 9 & 24.3 \\
\hline $56-65$ & 19 & 51.3 \\
\hline$\geq 65$ & 7 & 18.9 \\
\hline \multicolumn{3}{|l|}{ Stages } \\
\hline I & 27 & 72.9 \\
\hline II & 5 & 13.5 \\
\hline III & 3 & 8.1 \\
\hline IV & 2 & 5.5 \\
\hline \multicolumn{3}{|l|}{ ECOG-PS* } \\
\hline 0 & 25 & 67.5 \\
\hline 1 & 7 & 18.9 \\
\hline 2 & 3 & 8.1 \\
\hline 3 & 2 & 5.5 \\
\hline 4 & - & - \\
\hline \multicolumn{3}{|l|}{$\mathrm{LDH}^{* *}$} \\
\hline Normal (85-27 U/L) & 26 & 70.2 \\
\hline$>1-3$ times normal & 9 & 24.3 \\
\hline$>3$ times normal & 2 & 5.5 \\
\hline \multicolumn{3}{|l|}{ IPI Score ${ }^{* * *}$} \\
\hline $0-1$ & 30 & 81 \\
\hline 2 & 3 & 8.1 \\
\hline 3 & 3 & 8.1 \\
\hline 4 & 1 & 2.8 \\
\hline
\end{tabular}

have worse prognostic factors at diagnosis, higher relapse rates, and worse life expectancy. ${ }^{6}$ CA-125 serum level is also significantly higher in advanced LNH patients (stage 3 or 4 ) than in the early stages (stage 1 or 2 ). ${ }^{7}$ The biological information given by CA-125 serum is different from other serum markers such as levels of LDH released by lymphoma cells. The fact that LDH levels provide information about the number of tumor cells in the body and 
Table 2 Cancer Antigen-125 Serum Level in Diffuse Large B-Cell Lymphoma Patients at Dr. Hasan Sadikin General Hospital

\begin{tabular}{ccc}
\hline CA-125 serum levels & Number of Subject & Proportion \\
\hline $0-34 \mathrm{U} / \mathrm{mL}$ & 32 & $86.5 \%$ \\
$\geq 35 \mathrm{U} / \mathrm{mL}$ & 5 & $13.5 \%$ \\
\hline
\end{tabular}

Note: cut off point for CA-125 serum level of $<35 \mathrm{U} / \mathrm{mL}$

lymphoma proliferation activities, whereas an increase in CA-125 serum level reflects the patient's response to the potential for tumor invasion and provides a measure of infiltration activity. ${ }^{8}$ In light of the fact above, this study aimed to explore whether CA-125 serum levelscan serve as a tumor markers in the head and neck DLBCL.

\section{Methods}

This study was a descriptive observational study to determine the CA-125 serum level in DLBCL patients. The selection of study subjects was conducted by consecutive sampling. Patients who fulfilled the inclusion and exclusion criteria based on the order of patient arrival were recruited. Determination of sample size in this study was in accordance with the study objectives by using the formula for determining the sample size for study observational descriptive, a large sample formula was used. The minimum sample number was 37 subjects. The study was conducted at Dr. Hasan Sadikin General Hospital Bandung, at the Outpatients Clinic of Otolarhyngology Head and Neck Surgery in March-August 2018. The protocol of the study was approved by the Ethical Committee of Dr. Hasan Sadikin General Hosptal Bandung with no. LB.04.01/A05/EC/093/III/2018.

The Eastern Cooperative Oncology Group (ECOG) performance status (PS), were designated as followed: Status 0 Fully active, able to carry on all pre-disease performance without restriction; Status 1 Restricted in physically strenuous activity but ambulatory and able to carry out work of a light or sedentary nature, e.g., light housework, office work; Status 2 Ambulatory and capable of all self-care but unable to carry out any work activities; up and about more than $50 \%$ of waking hours; Status 3 Capable of only limited self-care; confined to a bed or chair more than $50 \%$ of waking hours; Status 4 Completely disabled; cannot carry on any self-care; totally confined to bed or chair and Status 5 death.

The IPI Score was used to determine the prognosis. The stage of LNH patients was defined as early stages (stage 1 or 2 ) and late stages (stage 3 or 4 ). CA-125 serum level (U/ $\mathrm{mL}$ ) was further measured and $<35 \mathrm{U} / \mathrm{mL}$ was the cutoff point value. Results were presented in tables in percentages.

\section{Results}

Of DLBCL patients included $(\mathrm{n}=37)$, male $(54.05 \%)$ was predominantly occurred compared to female. The age group of 5665 years was the most prevalent $(51.3 \%)$ and stage 1 DLBCL was the most $(72.9 \%)$ as shown in Table 1 . Most of the patients had ECOG-PS score $0(67.5 \%)$ and predominantly had normal LDH level (70.2\%), with the IPI score $0-1$ was the highest $(81 \%)$. Extranodal location was found in $13.5 \%$. Mean value of CA-125 serum levels in 37 subjects was $22.9 \mathrm{U} /$ $\mathrm{mL}$ (S.D 4.85), and most of them (86.49\%) had below $35 \mathrm{U} / \mathrm{mL}$ serum $\mathrm{CA}-125$ level as shown in Table 2.

\section{Discussions}

Our results showed more male (54.05\%) patients were found compared to female patients. This result is similar to the previous study from 13 hematology centers in Indonesia showing that the incidence of LNH is slightly more common in male than female, with a ratio of 1.6: $1.2 .^{3}$ Males are thought to be at greater risk of LNH because of smoking habits, occupational factors, and environmental exposure such as pesticides, however, studies to identify exposure patterns for the incidence of LNH has never been done in Indonesia. In Indonesia, farmers, forest workers, and agricultural workers are mostly men. Potentially dangerous exposures among these groups include pesticides that contain phenoxy acids, organophosphates, organochlorines, benzene, and other organic solvents. ${ }^{3}$

Interestingly, there is also an increase in the incidence of LNH based on age. Non-Hodgkin's lymphoma is more common in the productive group as shown in this study which is 45-64 age group. Diffuse Large B-Cell Lymphoma is 
like most cancers, the disease will increase with age, reflecting the damage to DNA of cells that accumulates over time. Damage can occur due to biological processes or from exposure to risk factors. A study clearly shows that there is a significant correlation between age and histopathology type of lymphoma. ${ }^{2}$

The mean CA-125 serum level is $22.9 \mathrm{U} / \mathrm{mL}$ (s.d.4.85); which is below $35 \mathrm{U} / \mathrm{mL}$. Individuals with CA-125 serum levels that exceeded cut-off $\geq 35 \mathrm{U} / \mathrm{mL}$ are diagnosed with advanced stage DLBCL. This result is following another study showing that CA-125 serum level will increase beyond the cut-off $\geq 35 \mathrm{U} / \mathrm{mL}$ at an advanced stage. This study also shows an association between high CA-125 serum level and the involvement of the lung, pleuro-pericardial or mediastinal peritoneum and/or abdomen in advanced LNH. An increased serum CA-125 level with involvement of pleural effusions could represent pleuro-peraticardial or peritoneal mesothelial cell responses to tumor activity. Lymphokine released by advanced LNH shows direct involvement by tumor activity as the main stimulus for CA-125 production. ${ }^{9}$

In this study, in outpatient clinic shows that most DLBCL stadium was in stage 1 as many as $72.9 \%$. There has been no previous study describing the epidemiology of the DLBCL stage. This can be estimated that the study has been conducted in the outpatient clinic. Patients with more advanced stages (stage 3 and 4) usually complain about diregional lumps other than the head and neck, and thus advanced DLBCL patients are not expected to visit the Outpatient Clinic of Otorhinolaryngology Head and Neck Surgery. Moreover, these patients have a good ECOG score performance status with a score of 0 is the most common since the respondents were in earlier stages. Stage is directly proportional to ECOG performance status, thus it supports the findings of this study that the stage 1 is the most prevalent, the ECOG performance status score is mostly equal as 0 which is optimal. ${ }^{10}$

Furthermore, the LDH serum levels were found normal for the early stage respondent. The LDH associated with several characteristics of diseases such as symptoms, tumor size, and organomegaly. Lactate dehydrogenase serum activity is increased in many cancer patients and thus may serve as a prognostic marker.11 The LDH serum is also found to be involved in tumor metabolism. The hallmark of most cancer cells is a metabolic change in which cancer cells depend on anaerobic respiration as the main energy source. This involves the production of lactate from glucose under a sufficiently oxygenated environment, known as the Warburg effect. Therefore, tumor cells take excess glucose and use it to accelerate growth and replication. Lactate dehydrogenase serum generally increases in disorders of lymphoid proliferation. In patients with $\mathrm{LNH}$, LDH serum levels have prognostic importance and thus can be used to monitor treatment response and recurrence. ${ }^{11}$

The results of our study show that the IPI score $0-1$ is the highest with $81 \%$ in the study subjects with normal CA-125 serum level, having a low risk with a 5-year life expectancy of $73 \%$. These results show that based on the calculation of the IPI component score of $81 \%$ of the DLBCL study subjects are found more at the age of $\leq 60$ years, stage 1 and 2 , normal LDH levels, no extranodal locations, and ECOGPS 0.

The limitation of this study is that the study method is an observational descriptive study, therefore, a further correlation between the increase in CA-125 serum level and stage, LDH level, IPI Score, ECOG-PS on DLBCL on the head and neck have not been performed due to lack of the study respondents numbers. Further study is needed to explore these associations.

In a conclusion, the CA-125 serum levels in DLBCL patients in the early stage are normal. An increased CA-125 serum level in DLBCL, especially at advanced stages suggests that CA125 serum levels may be of benefit as a tumor marker in the head and neck DLBCL. Further study is in need to explore the role of CA-125.

\section{References}

1. Kementerian Kesehatan Republik Indonesia. Data dan kondisi penyakit limfoma di Indonesia. InfoDatin Pusat Data dan Informasi Kementerian Kesehatan RI. 2015 [cited 2020 March 18] Available from: https://www.kemkes.go.id/resources/ download/pusdatin/infodatin/infodatinlimfoma.pdf

2. Dwianingsih EK, Indrawati, Hardianti MS, Malueka RG , Iswar RR, Sutapa S, et al. Histopathological features of lymphoma in Yogyakarta, Indonesia. Asian Pac J Cancer Prev. 2016;17(9):4213-16.

3. Badan Penelitian dan Pengembangan Kesehatan Kementerian Kesehatan RI. Riset Kesehatan Dasar (RISKESDAS) 2013. Jakarta: Badan Penelitian dan Pengembangan Kesehatan Kementerian Kesehatan RI; 2013

4. Cheson BD, Fisher RI, Barrington SF, 
Cavalli F, Schwartz LH, Zucca E, et al. Recommendations for initial evaluation, staging, and response assessment of Hodgkin and non-Hodgkin lymphoma: the Lugano classification. J Clin Oncol. 2014; 32(27):3059-67.

5. Ziepert M, Hasenclever D, Kuhnt E, Glass B, Schmitz N, Pfreundschuh, et al. Standard International prognostic index remains a valid predictor of outcome for patients with aggressive CD20+B-cell lymphoma in the rituximab era. J Clin Oncol. 2010;28(14):2373-2380.

6. Gutiérrez A, Martínez-Serra J, Barceló B, Sampol A, Vinas L, Gonzales G, et al. Prognostic value of serum CA125 levels in diffuse large B-cell lymphoma: potential role of a new sex and age adjusted reference value. Int J Lab Hematol. 2010; 32(6 Pt 2): 582-9.

7. Dilek I, Ayakta H, Demir C, Meral C, Ozturk M. CA 125 levels in patients with NonHodgkin lymphoma and other hematologic malignancies. Clin Lab Haematol.
2005;27(1):51-5.

8. Memar B, Aledavood A, Shahidsales S, Ahadi M, Farzadnia, Raziee HR, et al. The prognostic role of tumor marker CA-125 in B-Cell non-Hodgkin's Lymphoma. Iran J Cancer Prev. 2015;8(1):42-6.

9. Garg S, Goyal B. Evaluation of CA-125 as a prognostic marker in patients with Non-Hodgkin's lymphoma. International Journal of Medical and Health Research. 2017;3(4):13-5.

10. Paoli CJ, Bach BA, Quach D, Tsai KT, Wong B, Kallich J. Performance status of realworld oncology patients before and after first course of chemotherapy. The Journal of Community and Supportive Oncology. 2014; 12(5):163-70.

11. Yadav C, Ahmad A, D'Souza B, Agarwal A, Nandini M, Prabhu KA, et al. Serum lactate dehydrogenase in Non-Hodgkin's lymphoma: a prognostic indicator. Indian J Clin Biochem. 2016;31(2):240-2. 